\title{
地下水流出の流域における特性変化と場所的スケール \\ AVERAGING PROCESS AND SPATIAL SCALES OF GROUND-WATER-RUNOFF
}

\author{
高 木 不 折*.Fritz G. Rohde** \\ By FusetsuTAKAGI and Fritz G. ROHDE
}

\section{1. 序}

今日の 水文学のかかえている重要な問題に, (i)流域 を lumped system として扱うか, distributed system として扱うかということ, (ii) 流出現象のもつ場所的・ 時間的スケール，(iii）流域の構造をどのように捕える べきかということがら，さらに，(iv）流域内部で起こ る現象の物理的側面と確率統計的側面をどのように結び つけるべきかといった問題がある.

こうした問題については, これまでにもいくつかの研 究があるが，そのほとんどが主として短期間に起こる， いわゆる洪水流出を対象としており, 地下水の流出につ いては研究の蓄積も少なく，上にあげたことがらのほと んどが末知のまま残されているといってよい現状であ る.

従来考究されてきた lumped system として持つ流域 の特性は distributed system としての流域特性の総合 として理解されるべきものであり, 流域の内部で起こる 種々の物理的現象の統計的な意味での総合であると考え られる.また，こうした総合化は流域のもつ構造・スケ 一ルとの係わりで表面に現われてくるものであることは いうまでもない.

このように考えると, 流域全体としての性質が, 流域 内部での現象とどのように関連しつつ表に現われてくる かを論議する必要に迫られる，以上のように，冒頭にあ げたいくつかの問題は, 実はすべてが相互に密接な関係 を持っているのである. 本研究は, 地下水の流出現象を 対象として, 以上の問題を考究しょうとしたものであ る. そのために, 流出特性の基本ともいうべき低減特性 を取り上げ，理論的な検討をする一方，流域面積が 10 $\mathrm{km}^{2}$ から $100000 \mathrm{~km}^{2}$ にいたる本邦および西ドイッの

* 正会員 工博 名古屋大学助教授 工学部土木工学科

** Dr.-Ing. 西ドイツ,フーヘン工科大学教授 土木工学科
43 の流域について 実証的な考察を加えた.こうした考 察を基礎に，前記の問題それぞれについて新しい指針を 与えようとしたものである。

\section{2. 低減特性}

上記の目的のため, 本研究では lumped model ${ }^{1), 2)}$ と distributed model ${ }^{3), 4)}$ ，を用いる. 前者は，流域全体と しての低減特性を地下水帯内の流れの特性を基礎として 定義するものであり, 後者は, 流域内部での流出過程に おける低減特性の変化・平均化過程を議論するために用 いた．それらの基本的事項についてはすでに発表してい るので, 本章, 次章では 本論文に必要なことがら のみについて触れてお $<$.

長期間の不被圧地下水 の流出は, Fig. 1 のモ デルに代表され，基礎方 程式は, 地下水帯への水

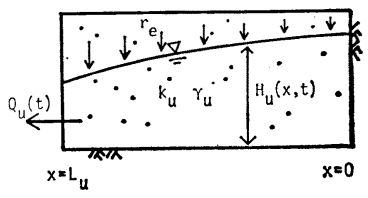

Fig. 1 Runoff model of unconfined component. 供給のない低減状態について，

$$
\frac{\partial H_{u}}{\partial t}=\beta H_{u} \frac{\partial^{2} H_{u}}{\partial x^{2}}, \quad \beta=k_{u} / r_{u}
$$

となる.この解, すなわち水位の変動状態は,

$$
\begin{aligned}
H_{u}(x, t)= & \frac{1}{\lambda t+1}\left\{-\frac{\lambda}{2 \beta} x^{2}+\frac{h_{u 0}-H_{u 0}}{L_{u}} x\right. \\
& \left.+\frac{\lambda}{2 \beta} L_{u} x+H_{u 0}\right\} \cdots \cdots \cdots \cdots \cdots \cdots
\end{aligned}
$$

となる. 上式中の記号は, $x$ : 位置座標, $t:$ 低減開始後 の時間, $H_{u}(x, t)$ : 水位, $L_{u}$ : 地下水帯の長さ, $k_{u}$ : 透水係数, $r_{u}$ : 間隚率である. 式 (2) 中の $\lambda$ は固有值で あって，初期・境界条件によって定まり，

$$
\lambda=\frac{2 \beta}{L_{u}{ }^{2}}\left(H_{u 0}-h_{u 0}\right)
$$

である. さて, 流出口の幅の要素を考慮すると, 河川で 
の地下水流出流量 $Q_{u}$ の低減は, 初期流量を $Q_{u}$ とし て次式で与えられる.

$$
Q_{u}(t)=Q_{u 0} /(\lambda t+1)^{2}
$$

この低減の割合を与える $\lambda$ は, 実は初期流量 $Q_{u}$ と次 の関係にあることが示される.

$$
\lambda=K \sqrt{Q_{u 0}} \text {. }
$$

すなわち，低減曲線は，

$$
Q_{u}(t)=Q_{u 0} /\left(K \sqrt{Q_{u 0}} t+1\right)^{2}
$$

となる.

こうして定義された $K$ も流出流量の低減の状態を与 えるが，これは流域の地形・地質的要素と流域内部の水 の場所的な分布状態によって決定される值である ${ }^{2)}$.す なわち，水の場所的な分布状態が，場合場合で変化しな い流域では， $K$ は流域固有の值となる．この意味で, ここでは $K$ を地下水流出の低減特性值として扱らこと にする.

\section{3. 流域水の挙動に関する変分原理}

\section{(1) 流域と力学系}

流域を面的に見ると，流域の上流部より流出した水 は, 途中の流出水を集めながら順次下流へと流下し, や がて流域最下流端に達する.このように，巨視的には， 流出現象は一方向的に見えるが，地下水流出について考 えると, 平地や盆地地域などでは河水と河川周辺の地下 水は互いに干渉しており，かつ必ずしも一方向的ではな く，下流側の状態いかんによっても上流部の水の挙動が 定められている.すなわち,こういう領域は水の挙動に対 して1つの力学系を構成しているのである ${ }^{3)}$.このよう に考えると，地下水の流出，流下システムは， Fig. 2 に示すような力学系の直列および並列の一方向的な連鎖 からなっていることがわかる．個々の力学系では，河 水・地下水といった流域水がそれぞれ干渉して系全体と しての挙動をし, その結 果として流出水は系の最 下流端より次の力学系へ と流下しているのであ $3^{3), 4)}$.

実際の流域で，このよ らな力学系がどのような 領域に対応するかについ ては，まだ定まった考え 方はない、それは，われ われの眼に直接触れる表 面流出の現象とは異なっ て, 地下水流の場が地下

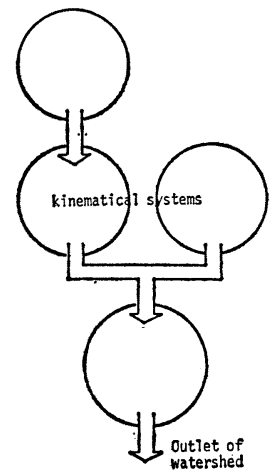

Fig. 2 Watershed as links of kinematical systems.
に 3 次元的な広がりを 持っているので, これ までは概念的な説明 5 がされてきたに過ぎな い.こうした力学系を 流域構造と結びっけよ うといらのも本論文の 意図の一つである.

\section{（2）変分原理}

Fig. 3 は前節で述 べた 1 つの力学系であ る3). この力学系は河 川水と地下水（それぞ れの運動の場を $S, G$

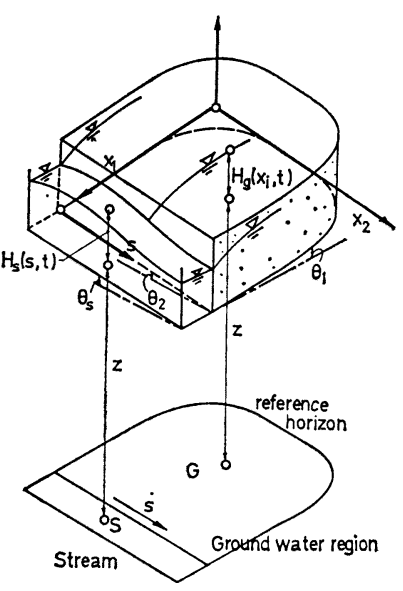

Fig. 3 A kinematical system
と記す）からなり，これらの成分水は互いに干渉し合い ながら系全体として挙動している. 両者の干渉も含めた それぞれの挙動，すなわち，この系全体としての挙動は 次の変分原理に従っている.

$$
\delta\left\{\int_{G} \boldsymbol{L}_{g} d x_{i}+\int_{S} \boldsymbol{L}_{s} d s\right\}=0 .
$$

ここに,

$$
\begin{aligned}
\boldsymbol{L}_{g}= & r \frac{\partial H_{g} *}{\partial t}+\sum_{i=1}^{2} \frac{1}{2} k H_{g} *\left(\frac{\partial\left(H_{g}+z_{0}\right)}{\partial x_{i}}\right)^{2} \\
& -r\left(H_{g}+z_{0}\right) \\
\boldsymbol{L}_{s}= & B_{s}\left(H_{s}+\varepsilon+z_{0}\right) \frac{\partial H_{s} *}{\partial t}+\frac{2}{3} \frac{B_{s}}{n} H_{s} * \ldots+\cdots \cdots \cdots \cdots \\
& \cdot\left\{-\frac{\partial\left(H_{s}+\varepsilon+z_{0}\right)}{\partial s}\right\}^{3 / 2} \cdots \cdots \cdots \cdots \cdots \cdots \cdots
\end{aligned}
$$

であっで), これらはそれぞれ地下水, 河川水の local potential とよばれる. また，上式中の諸記号は以下の とおりである.

$x_{i}$ : 地下水の運動の場に対してとった直角座標, $i=1,2$,

$s:$ 河川の流れ方向, および地下水領域 $G$ の周 辺にそった距離，反時針方向を正とする，

$z_{0}$ : 基準水平面より，不透水面（層）および河床 までの鉛直高,

$\theta_{i}, \theta_{s}$ : 不透水層の $x_{i}$ 方向 $(i=1,2), s$ 方向と水平 のなす角, $\sin \theta_{i}=-\frac{\partial z_{0}}{\partial x_{i}}, \sin \theta_{s}=-\frac{\partial z_{0}}{\partial s}$, ま た $k \sin \theta_{i}=f_{i}$ と記す,

$H_{g}\left(x_{i}, t\right):$ 地下水深 $H_{g}\left(x_{1}, x_{2}, t\right)$ の略記,

$H_{s}(s, t):$ 河川水梁,

$n:$ マニングの粗度係数,

$B_{s}:$ 河川幅,

$\varepsilon:$ 河水のもつ速度水頭,

$r:$ 地下水層の間隚率,

$r$ : 地下水帯単位面積あたりの水供給強度, 
$\int_{G} d x_{i}:$ 面積積分 $\iint_{G} d x_{1} d x_{2}$ の略記,

$\int_{S} d s:$ 河川にそっての線積分,

なお, 式 (7) の変分計算に際しては, $H_{g}{ }^{*}\left(x_{i}, t\right)$, $H_{s}{ }^{*}(s, t)$ をいったん固定したうえで, $H_{g}\left(x_{i}, t\right)$, $H_{s}(s, t)$ のみについて変分を考え, その結果を補助条 件式

$$
\left.\begin{array}{l}
H_{g}\left(x_{i}, t\right) \equiv H_{g} *\left(x_{i}, t\right) \\
H_{s}(s, t) \equiv H_{s}^{*}(s, t)
\end{array}\right\}
$$

とともに用いなければならない.この $H_{g}{ }^{*}, H_{s}{ }^{*}$ は現実 に起こる水深分布であって, 式 (7) の変分は $H_{g}{ }^{*}, H_{s}{ }^{*}$ のまわりの仮想変位 $\delta H_{g}, \delta H_{s}$ について考えるのであ る.また,

$$
\left.\begin{array}{l}
\left|H_{g}^{*}\left(x_{i}, t\right)\right| \gg\left|\delta H_{g}\left(x_{i}, t\right)\right| \\
\left|H_{s} *(s, t)\right| \gg\left|\delta H_{s}(s, t)\right|
\end{array}\right\}
$$

と考えている.

式 (7)の Euler-Lagrange 方程式および河川 $S$ と地 下水帯 $G$ の境界での自然境界条件は, それぞれ地下水 の運動方程式, 河水の運動方程式を両者の干渉をも含め て表現するのである. なお，この変分原理のもつ物理的 意義などについては参考文献に譲る4).

\section{4. 力学系における低減特性の変化}

前節の原理を低減特性の流域内部での変化過程の議論 に応用するために， Fig.

4 に示すモデルを考え る3). このモデルは $1 つ$ の力学系を示したもの で, 性質を異とする $n$ 個 $(j=1,2, \cdots, n)$ の地下 水の領域, 河川部分から なっているものとする. 取り扱いを簡単にするた めに, 河水も地下水も一 次元的な流れをするもの と考えよう. 地下水の運 動は前述の不被圧地下水 の挙動, 式 (2) で表現さ

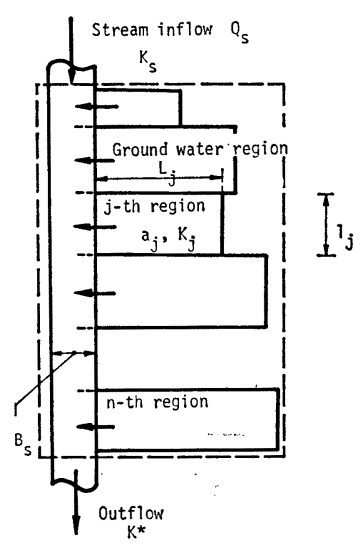

Fig. 4 Kinematical system. れるが,もし河川との干渉などがなければ, $j$ 番目領域で の地下水流出の低減汢式 (3) の $\lambda_{j}$, あるいは式 (6) の $K_{j}$ といら特性を持っているものとする. 添字の $j$ は $j$ 番目領域の值を意味している. さらに, 河川の上流端か らは，低減係数 $K_{s}$ をもった式 (6) 型の流入があるもの とする. また, この水は系内の流出水と干涉するが, 系 全体としての挙動, すなわち, 低減特性を $\lambda^{*}$ あるいは $K^{*}$ と記すことにする.
さて，考えている力学系全体としての挙動を算定する ためには，適当な試験関数を式 (8)，(9) の $H_{g}, H_{s}$, $H_{g}{ }^{*}, H_{s}{ }^{*}$ に用い, 式 (7) の変分原理が成立するように 試験関数に含まれる未知パラメーターの值を決定すれば よい.この試験関数として, 地下水深 $H_{g j}, H_{g} *$ につ いては，それぞれ $\lambda_{j}, \lambda *$ をパラメーターとする式 (3) の型のものを用い，河川では時間的水深変化は式 (2) と 同様 (パラメーターは $\lambda_{s}$ ) で，かつ河川区間で場所的 には直線的な水深分布をするものと考元た．

このような仮定に立つと, 式 (7) の変分原理は, 場お よび河川に沿っての積分であるから，

$$
\begin{gathered}
\delta \cdot \sum_{j}\left\{\int_{G_{j}} \boldsymbol{L}_{g j}\left(x, t, \lambda_{j}, \lambda^{*}\right) d x_{i}\right. \\
\left.\quad+\int_{s_{j}} \boldsymbol{L}_{s j}\left(s, t, \lambda_{s}, \lambda^{*}\right) d s\right\}=0
\end{gathered}
$$

と書かれる. 近似計算ではあるが，この式が成立するよ うな $\lambda *$, すなわち, 系全体としての挙動を表わす $\lambda^{*} の$ 值が求められ, さらに, これを低減特性 $K^{*}$ に書き改め ると，

$$
K^{*}=\frac{\sum_{j} p_{j} q_{j}{ }^{3 / 2} K_{j}-\frac{B l}{C} q_{s}^{3 / 2} K_{s}}{\sum_{j} p_{j} q_{j}} \cdots \cdots \cdots \cdots
$$

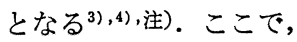

$p_{j}: j$ 番目地下水領域の地形地質条件で定まる定 数,

$q_{j}, q_{s}$ : 初期時の下流端流量, $j$ 番目領域からの地下 水流出流量, 上流上り流入する河川流量をそ れぞれ， $Q_{u 0}, Q_{u 0 j}, Q_{u 0 s}$ としたとき，

$$
\left.\begin{array}{l}
q_{j}=Q_{u 0 j} / Q_{u 0}, \quad q_{s}=Q_{u 0 s} / Q_{u 0}, \\
q_{s}+\sum_{j} q_{j}=1
\end{array}\right\} \ldots
$$

すなわち, 初期時の最下流端流量のうち, ど れだけが系内の地下水領域からの流出水か,

またどれだけが上流部よりこの系内に流入 した河川水かを示す.

$B:$ 河川幅

$C: Q=\mathrm{CH}_{s}{ }^{2}$ と近似した場合の係数

$l:$ 河川長

である.

さて，式 (13) は，上流より低減特性 $K_{s}$ で河川を通 じてこの系内に入った河川水は, 系内の水と干渉し, 地 下水領域（低減特性 $K_{j}$ ）からの流出水を合わせて, 最 下流端からは新たな低減特性 $K^{*}$ で流下・流出すること を意味している.式 (13) の形式からわかるように，こ

注）式 (13) の誘導の考え方については, 文献 3) を参照さ れたい.ここでは文献 3）の場合とは異なり，よりくわ しく local potential (8), (9) を用いて $K^{*}$ を求めた が, その結果の式 (13) はやはり文献 3) の結果と等し い式となった. 


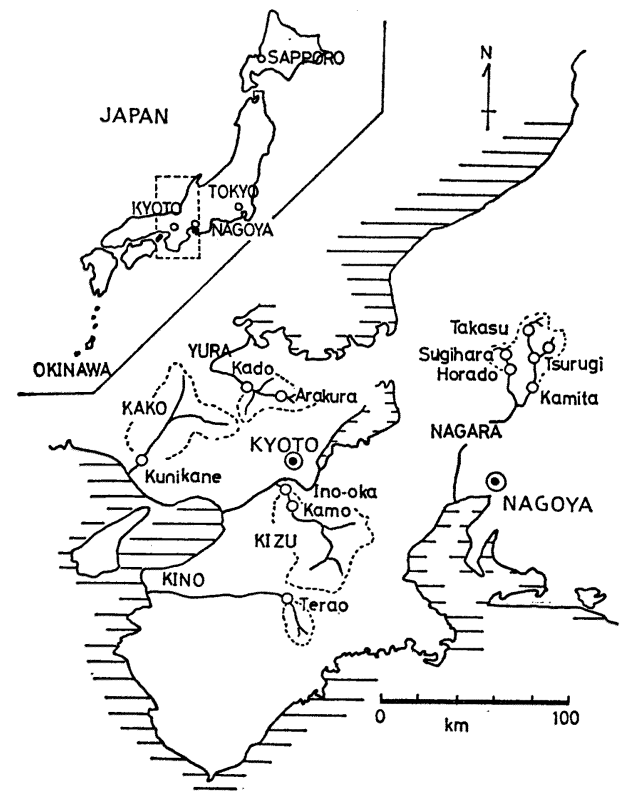

(a)

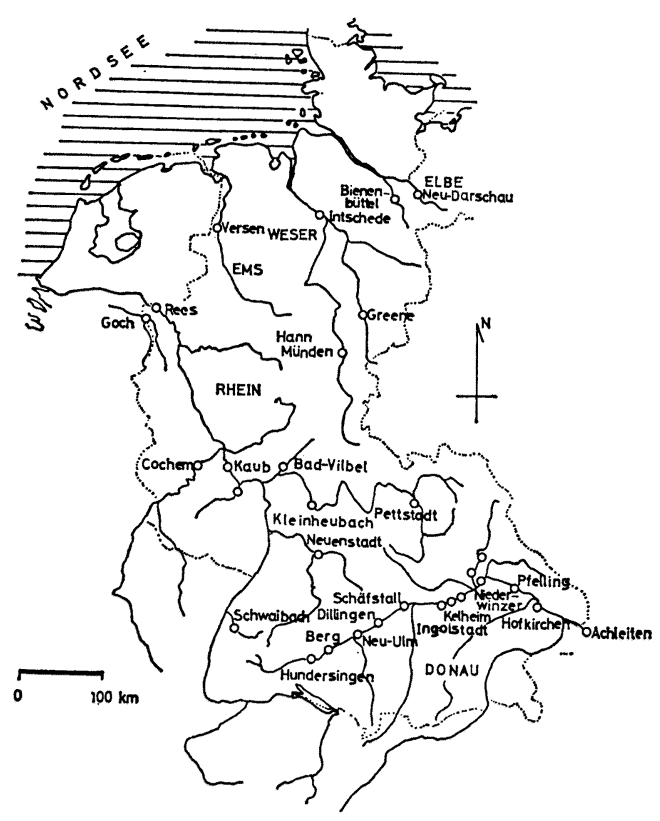

(b)

Fig. 5 Watersheds concerned.

の場合 $K^{*}$ は $K_{j}$ と $K_{s}$ の一次結合, あるいは重みつ き平均になるのである.なお, 実際の流域は力学系の連 鎖であって，このような平均化がそれぞれの力学系で何 段階も繰り返されているのである.

\section{5. 解析対象流域と低減特性値}

解析の対象としたのは, Fig. 5 に示す本邦 17, 西ド イッ 26 の合計 43 流域である ${ }^{7}$. 流域の詳細については 割愛するが, 各流域それぞれで数多くの低減部を解析し た結果得られた低減特性 $K$ の分布状態の例を確率分布 密度の形式で Fig. 6 に示す.

\section{6. 低減特性と流域地形}

\section{（1） 低減特性と流域面積}

低減特性 $K$ の值は, 流域の地層構造（地下水帯の幅, 長さ), 地質的条件（透水係数や間隙率など）と流域内 部の水の場所的分布状態で定まるが，もし流域の幅（地 下水帯の長さ） $L_{u}$ と流出口の幅（河川に沿った流域の 長さ） $B_{u}$ と流域面積 $A$ とが，それぞれ

$$
B_{u} \propto \sqrt{A}, L_{u} \propto \sqrt{A}
$$

の関係にあるものとすると, 低減特性 $K$ は流域面積と 反比例することが理論的に導かれる2).

$$
K \propto A^{-1}
$$

さて, Fig. 7 は実際の流域で求めた低減特性の平均

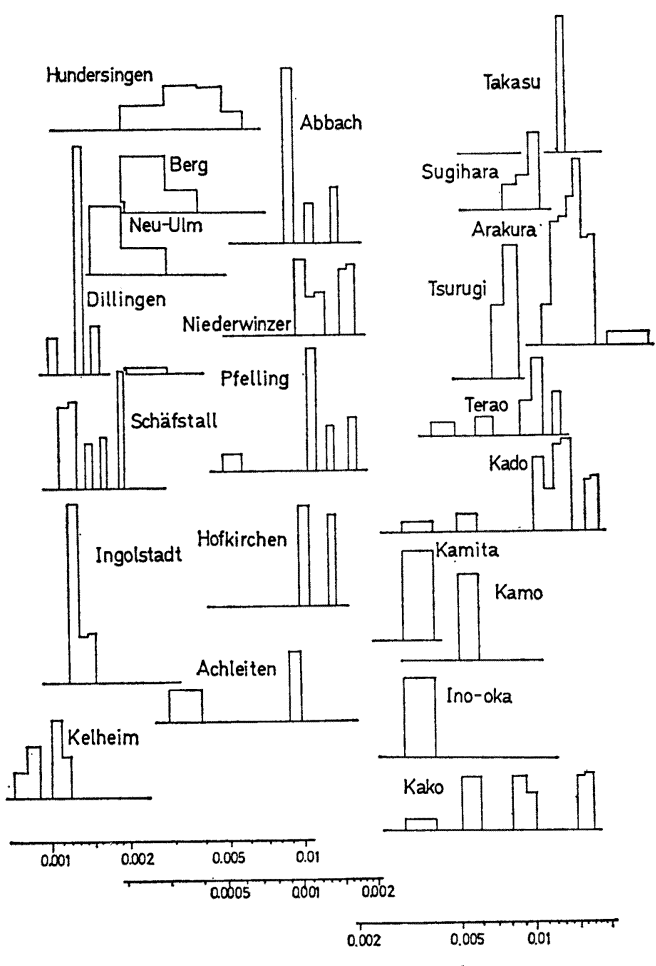

Recession factor $K\left(\mathrm{~m}^{-3 / 2} \mathrm{Sec}^{1 / 2} \mathrm{day}^{-1}\right)$

Fig. 6 Distribution of recession factor $K$.

值 $K_{0}$ をそれぞれの流域面積 $A$ に対してプロットしたも のである. すべてのプロットについては, 両者の間に式 （16）のような一定の関係はみられないが，図に示した 


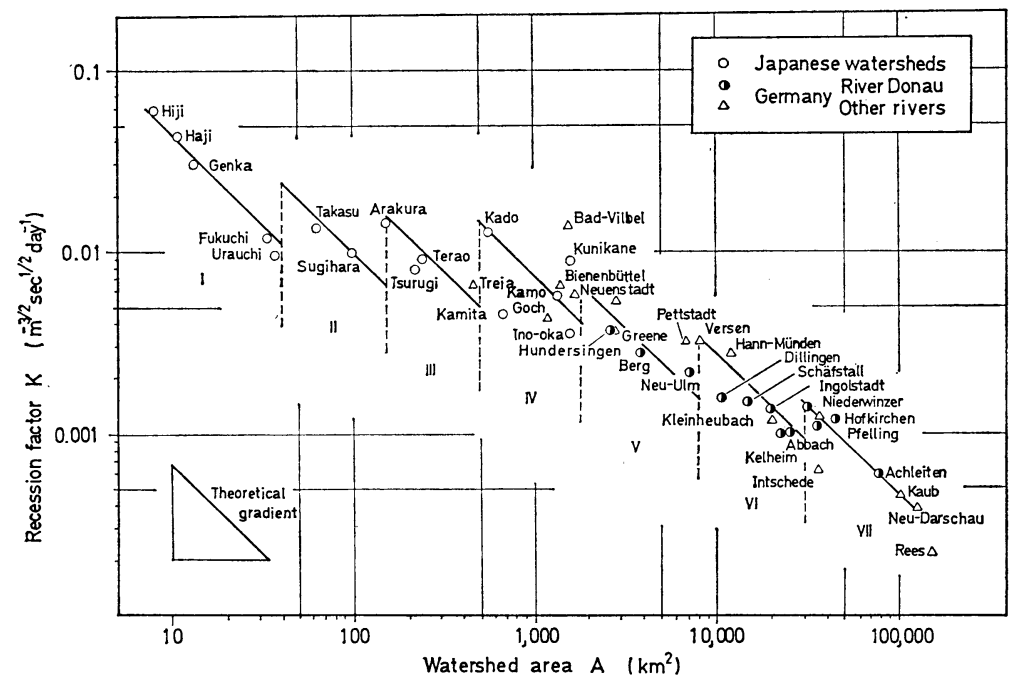

Fig. 7 Relationships between watershed area $\mathrm{A}$ and the mean recession factor $K_{0}$.

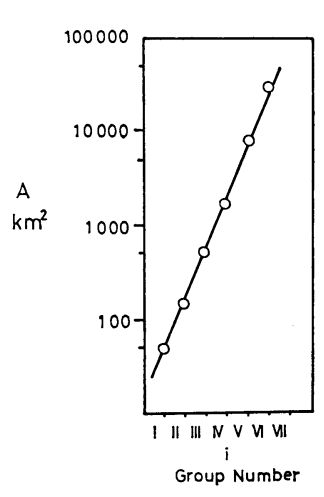

Fig. 8 Watershed area and group numbers.

と, 低減特性が流域面積の増加 に対して不連続的に変化した直 後の流量観測点は, 大きな支川 との合流点のすぐ下流，あるい
Table 1 Grouping of watersheds.

\begin{tabular}{c|c}
\hline group number & catchment area $\mathrm{km}^{2}$ \\
\hline I & $\sim 50$ \\
II & $50 \sim 150$ (or 200) \\
III & $150 \sim 500$ (or 700) \\
IV & $500 \sim 1600$ \\
V & $1600 \sim 8000$ \\
VI & $8000 \sim 30000$ \\
III & $30000 \sim$ \\
\hline
\end{tabular}

ように, 流域面積によっていくつかのグループに分ける と, それぞれのグループの範囲内では, すなわち流域面 積のある範囲内ではちょうど式 (16) と同様の関係が $K$ と $A$ との間に成立していることがわかる.

このように, 低減特性のもつ性質が流域面積によって かなり明膫にグループ分けできるのは, 地下水流出につ いての 1 つの場所的スケールの現われにほかならない. すなわち, それぞれのグループの範囲内の流域では, 地 下水流出は同一の場所的スケールに属し, 違ったグルー プの現象は互いに異なった場所的スケールの現象に属す のである.こうしたグループの流域面積の範囲を Table 1 に示す.

\section{（2）地下水流出と流域オーダー}

低減係数は流域面積の増加とともに徐々に連続的に変 化するが, 流域面積がある限界を越すと不連続に変わ り，新しいグループでまた連続的に変化している.この ような構造は流域自体のもつ構造と深い関係にある.す なわち, 河川に沿って上流から下流へと進めば, ある範 囲では集水面積は徐々に連続的に増加するが，河川がか なり大きな支川を含むと, 集水面積は合流点の上下で不 連続的にに変化する.こうした眼で Fig. 7 を振り返る
はやや下流に位置していることが見られる，たとえば, 由良川の角観測点 は高屋川との合流点の少し下流の位 置にあり, Donau 川では, Neu-Ulm, Niederwinzer, Ingolstadt, Hofkirchen, Pfelling などの観測点, また, Weser 川の Intschede といった観測点も同様な位置に ある.こうした事実から, 上述のグループの境界, 低減 特性值の不連続な変化は, 本川の集水域と支川のそれに おける特性の差違, あるいは水の分布状態の差違による ものと考えられる.

Fig. 8 は Table 1 にあげた各グループの流域面積 の限界值を, グループ番号 $i$ に対してプロットしたもの である.ひとめでわかるように， $i$ 番目グループの限界 流域面積について, 次の関係式が成立する.

$$
A_{i} / A_{i+1}=0.27 \text { (=constant), } i=\mathrm{I}, \mathbb{I}, \cdots \cdots \text { (17) }
$$

この式はいわゆる流域面積則と同じ構造をしている. 流 域面積則は, オーダー $u$ の流域の平均面積 $\bar{A}_{u}$ は $R_{a}$ または $V$ を一定值として,

$$
\bar{A}_{u}=\bar{A}_{1} \cdot R_{a}{ }^{u-1} \text { または, } \bar{A}_{u} / \bar{A}_{u+1}=V \cdots \text { (18) }
$$

と書かれ, $R_{a}, V$ の值は大略 $R_{a}=3 \sim 4, V=0.30 \sim 0.25$ であるといわれてきた6). このように, 式 (17) と式 (18), そしてそれぞれの一定值の值を比較すれば, 前述 のグループ分けは, 実は流域のオーダーと深い関係にあ ることがわかる。

\section{（3）地下水流出と流域地形}

河道のオーダーという概念は, 物理的な観点からみる と, 非常に長い時間スケールではいわゆる浸食過程に対 するものであり, 流出という点では浸食過程の結果生れ た河道の集水過程, 特に流域の地表近辺での集水状況を 表現しようとするものである. 水文学の分野では, それ 
は主として地表近辺で起こる直接流出の現象との関連で 考究されてきた.

一方, 地下水流出のもつ主要な特性は主として地下水 帯内部での流動機構によって支配され, その結果がいわ ゆる低減特性や貯留遅延効果といった形式でわれわれの 眼に触れると考えられてきた. ところで, 地下水の流出 といっても, 地表流出した水を対象としているわけ で, 本来, 流域の地表近辺の性質と無関係ではありえな い. こうした地表近辺の問題は, 従来は地下水の流出 口, いいかえれば, 地下水帯と地表の交わりといったご く概念的な形式で扱われていたにすぎない1).

ところで, 本章で観察された事実, 流域面積による場 所的スケールと流域オーダとの関倸は, 地下水流出の現 象と河道網, 集水状況といった流域の地表形状との倸わ りを明瞭にしている. 換言すれば, 地下水流出の特性も 直接流出などと同様に流域の地表近辺での性質にかなり 支配されていることになる.しかしながら，この事実は， 「地下水流出の諸特性が, 流出の母体, 地下水帯内での 流れの力学的機構によって定まる」といら従来の基本的 考え方 $^{1,2)}$ と矛盾するものではない. 低減の状態が, 地 下水帯内の流れによって基本的には式 (6) の関数形で与 えられることを忘れてはならない，また，ここでは集水 状況・地表近辺の状態を述べたが, これはまた地下の地 下水帯の広がり, 地下の構造とも密接に倸わりあってい る.こうした流域の構造については後に議論する.

\section{7. 流出過程における低減特性の平均化}

\section{（1） 低減特性のばらつき}

以上，それぞれの流域での低減特性 $K$ の平均值につ
いて議論した. 前述したように, 実際には $K$ の值は流 域面積ばかりでなく, 低減開始時の流域の状態, 水の場 所的な分布状態によって变化し，1つの流域であっても 必ずしも固有の值とはならずに変化する.

Fig. 9 は Fig. 7 と同様な図に, 各流域での $K$ の 值のばらつきの範囲を直線で重ねて示したものである. この図には特に詳細な解析をした流域についての值のみ を記し,さらに, 数か所の流域については $K$ の值の分 布状態も示した。図を見ると, まず流域面積が $50 \mathrm{~km}^{2}$ 以下の非常に小さい第 I グループ の流域では， $K$ の值 はばらつきの小さい流域固有の值となっていることがわ かる.また，第IIグループ以下の流域では，それぞれの グループの範囲内では, 流域面積の増加とともに $K$ の ばらつきの範囲が徐々に減少している. 図中の点線はこ の傾向を示したものである.

前述したように，大きな支川との合流点のやや下流の 観測点, 寸なわち， $K$ の值が不連続に変化した直後で は, $K$ の值は大きく変化し, 角, 国包, Pfelling の例 に見られるように，1段階小さいグループの值に対応す るような值を取っている場合も見受けられる. 後述する 流域の構造とも合わせ考えると，このことはこれらの流 域では，支川の性質が表に現われず，本川の性質によっ て $K$ の值が決定される場合もあることを意味している. いいかえると, 本川の集水域と支川の集水域からの流出 流量の比といった, 流域内部の水の場所的な分布状態に よる影響の現われを暗示しているといってよい.

このような大きなばらつきを持った特性も, さらに集 水流下寸るにつれ，徐々にばらつきの少ない流域固有の 值に近接している. この過程は, 流域内部での集水流下 過程での平均化の状態の現われとしてきわめて暗示的で ある。

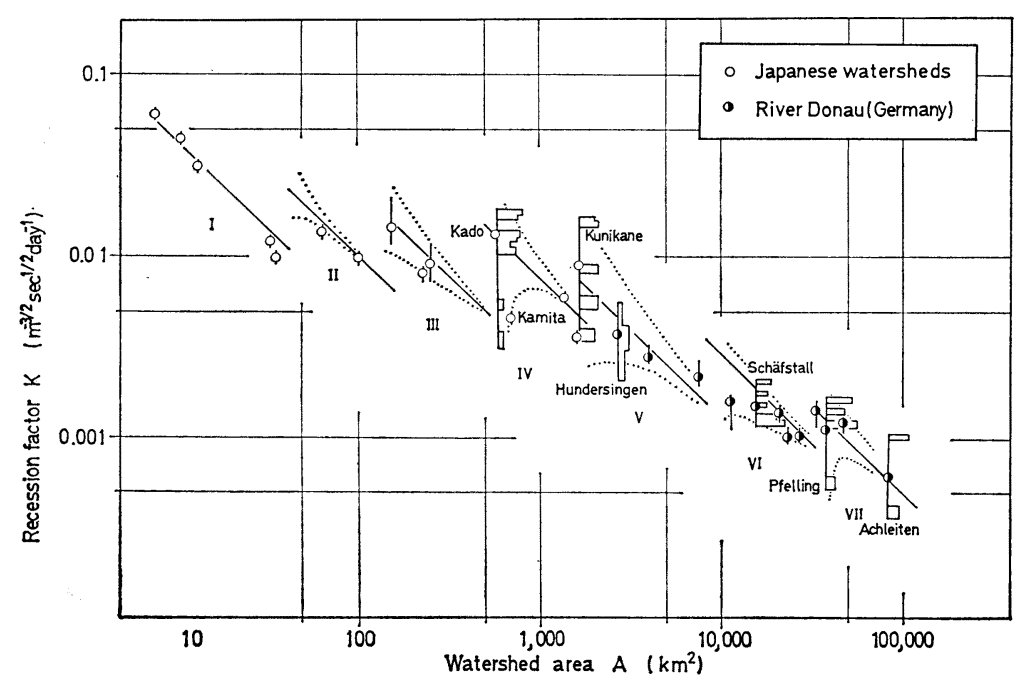

Fig. 9 Scattering of the recession factor $K$.

\section{（2）低減特性の平均化過程}

流域内部での低減特性の変化 については 4. で論じ, 式 (13) を得たが，実際の流域での解析 で得られる低減特性 $K$ の值は， 実は式 (13)の $K^{*}$ に対応す る.上に述べたことがらは, $K^{*}$ の值が流域固有の值を常にとる 流域や，場合場合に応じてかな りばらつく流域があることを示 している.いま，式（13）をふ り返ると， $K^{*}$ はある力学系へ の河川流入水のもつ特性 $K_{s}$ と 系内からの流出水の特性 $K_{j}(j$ $=1,2, \cdots, n)$ の 加重平均とな 
っている．この観点に立てば， $K^{*}$ が常に流域固有の值 をとるのは，以下に述べる 2 つの場合であると考えてよ い.

i ）流域内部の水の場所的分布状態，すなわち，下 流端流出水のらちどれほどが, 上流よりの河川流入水 に, また系内の地下水流出に依存するかといら量, 式 (14) の $q_{s}, q_{j}$ が常に一定しており, したがって, 平均 化の重みも一定している場合.

ii ）たとえ，水の分布状態 $q_{s}, q_{j}$ が変化し，重みが 変化しても, 非常に流域が大きいか, あるいは多種多様な 地質が複雑に組み合わさっているために,すなわち, $n$ が 非常に大きいために, いわゆる平均化過程が卓越して, その結果として $K^{*}$ の值が外見上ほぼ一定となる場合.

前述した流域面積の小さいグループ (Fig. 9 参照) で固有の低減特性が現われるのは，上のｉ）の場合に対 応している. また, 各グループで流域面積が大きくなる と $K$ が一定值となっているのは ii) の場合に対応して いる. そして，これら以外の流域については，場合場合 の水の分布状態いかんによって, $K$ が種々の值を取り うるのである.

いま, Fig. 9 で流域面積 $585 \mathrm{~km}^{2}$ の角地点と, 面積 $713 \mathrm{~km}^{2}$ の長良川・上田地点とを比べると興味深い. こ の 2 地点は, 流域面積の大小関係が逆であるにも係わら ず, 前者は第IVグループに属し, 後者はあたかも第正グ ループに属するかに見える. そして前者のばらつきは大 きく, 後者ではほとんど一定值となっている. 角地点の ばらつきについては，すでに (1) で触れた.ところが, 後者の上田地点について特に興味樑いのは,「その上流 流域がきわめて複雑な地質状態であること」である.す なわち, 非常に多種多様な地質の領域 (しかも一つ一つ はかなり狭い) が互いに複雑に入り混じって流域を構成 している. そして,その複雑さは, 上田観測点と上流部の 剣観測点の間の領域ではなはだしい。すなわち, 上田流 域の場合には前述した ii) の平均化が特に卓越し, それ がために流域固有の $K$ 值が観察されるのである.

\section{（3）実際の流域での解析} 例

一つ一つの力学系での低減 特性の変化, あるいは平均化 過程は式 (13) で与えられる. いま, 流域を Fig. 10 に示 寸力学系の連鎖と考元, $i$ 番 目の力学系を考えよう.この 系内の性質を異にする $j=1$, $2, \cdots, n_{i}$ 個の地下水帯の低減 特性を $K_{i j}$ とし, 最下流端

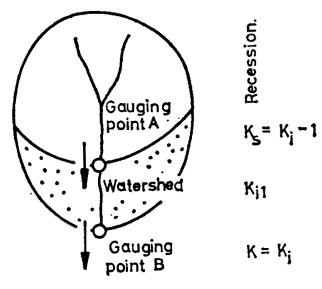

Fig. 11 Conceptual explanation of the kinematical system concerned.

での低減特性を $K_{i}$ (前述の $K^{*}$ に相当する), 河水と しての流入水の特性 $K_{s}$ は, $i-1$ 番目領域よりの流出 水の特性に等しく $K_{i-1}$ と記す.このようにすると, 式 (13) は,

$$
K_{i}=\sum_{j=1}^{n_{i}} a_{i j} q_{i j}{ }^{3 / 2} K_{i j}+b_{i} q_{i s^{3 / 2}} K_{i-1}
$$

と書き改められる.ここで， $a_{i j}, b_{i}$ は，それぞれ系内 $j$ 番目地下水帯, 上流上りの河川流入水が平均化過程で もつ重みの係数であり, また， $q_{i j}, q_{i s}$ は $i$ 番目系につ いての $q$ (式 (14) 参照) の值である.

式（19）を実際の流域で検証するためには，実は系内 部についての多くの情報が必要ではあるが,このように 多くの観測のされている流域はほとんどない. そこで, ここでは, Fig. 11 に示すように一つの河川に沿って上 流 $\mathrm{A}$ 地点, 下流 $\mathrm{B}$ 地点で観測がされている所を取り上 げ, この $\mathrm{AB}$ 両地点間の残流域を第 $i$ 番目の力学系と して考えることにする. さらに, この系の内部の詳細は 扱わず， $j=1$ すなわち，系の内部はまったく一様であ るものとして解析した.

ここでの解析の対象としたのは, 西ドイッ 9 領域, 本 邦 2 領域である. 実際の解析では, 数多くの低減状態に ついての $\mathrm{A}, \mathrm{B}$ 地点での情報 $K_{i}, K_{i-1}, q_{i 1}, q_{i s}$ より, 逆に系内部の状態 $K_{i 1}, b_{i} / a_{i 1}$ を評価するという方法を とった.

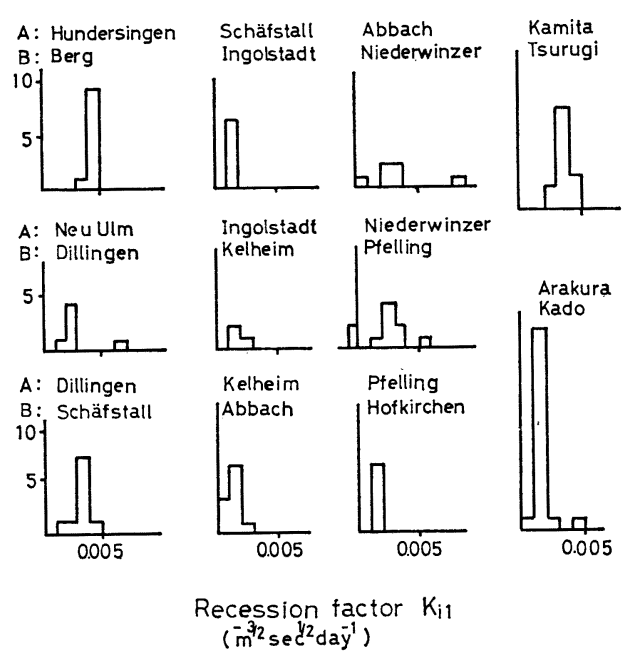

Fig. 12 Histogram of recession factor $K_{i 1}$. 


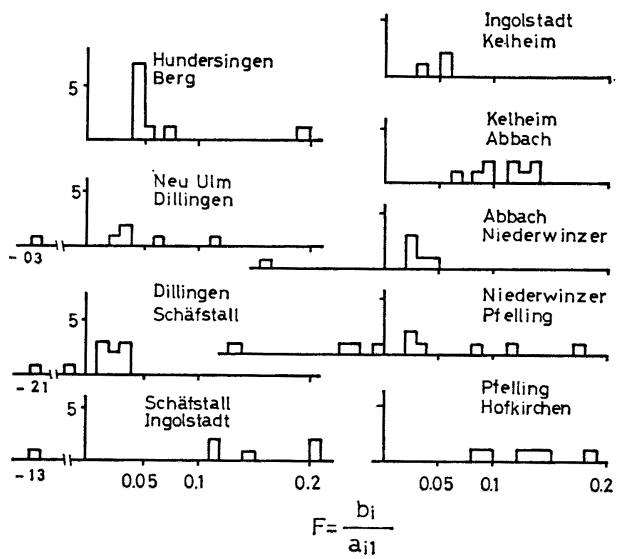

Fig. 13 Histogram of the factor $F$.

Fig. 12 はこのようにして求められた，「AB 両地点 間の領域の低減特性值 $\left.K_{i 1}\right\lrcorner$ の分布状態をヒストグラム として示したものである. 二,三の領域では $K$ の值にか なりのばらつきが見られるが，ほとんどの領域では，分 布形はシャープであって，それぞれの領域（系内部）で の特性量としてほぼ一定の $K_{i 1}$ の值が見い出される.

一方, 上流上りの流入水々, 系内の地下水流出水の平 均化過程での保数の比

$$
F=b_{i} / a_{i_{1}}
$$

を考えよう．この $F$ の值をやはりヒストグラムとして 示したのが Fig. 13 である. 理論的には， $b_{i}, a_{i 1}$ の值 は流域の地形地質状態, 河川の状態などで定まり, 個々 の力学系では一定であって，したがって，Fもまた一 定の值である.しかし，Fig. 13 では，Fが一定值と考 えられるのは 1,2 の領域にすぎず，多くは非常に広い 範囲にばらついている.ここでの解析計算では, 上下 流 $\mathrm{A}, \mathrm{B}$ 地点の值より間接的に内部状態を算定してお り，しかも，かなり誤差が入りやすい計算になってい る. また, 力学系の取り上げ方, 系内を一様と仮定した などのことがらによって，Fの值が大きなばらつきを示 しているものと思われる．ただ，ここで特に注意すべき は，F の值は大きくとも 0.2 以下程度であることであ る.また， 0.1 あるいはそれより小さい值を取っている 場合が多いことも記憶にとめておこう。

\section{（4）平均化過程における河川水の役割}

一つの力学系内での低減特性の平均化過程にあって, 上流上りの河川流入水の特性 $K_{i-1}$, おょび系内の地下水 流出水の特性 $K_{i 1}$ のもつ重みは, 式 (19) より, それ ぞれ

$$
w_{i s}=b_{i} q_{i s^{3 / 2}}, \quad w_{i j}=a_{i j} q_{i j}{ }^{3 / 2}
$$

である. ここでの解析では， $j=1$ であるから, 前者の 後者に対する比は,

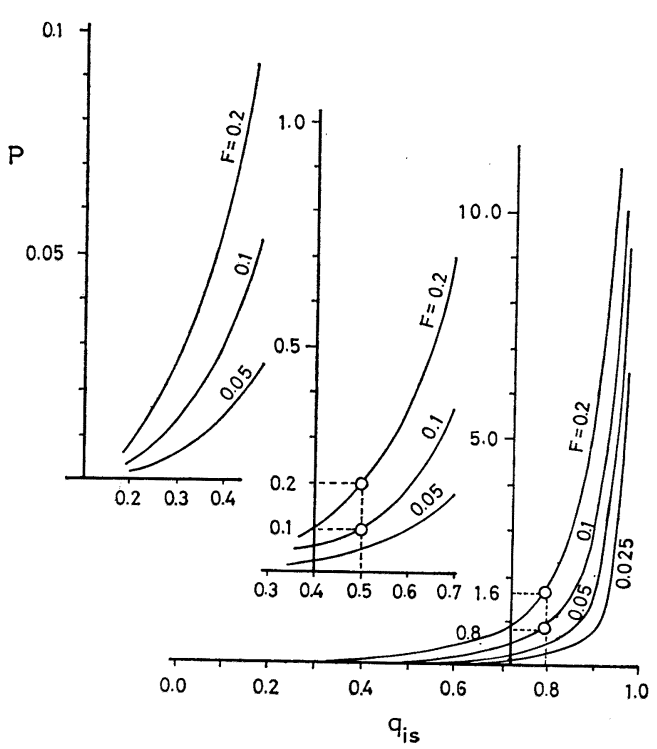

Fig. 14 Weight of stream inflow in averaging process.

$$
P=\frac{b_{i} \cdot q_{i s}{ }^{3 / 2}}{a_{i 1} \cdot q_{i 1}{ }^{3 / 2}}=F \times\left(\frac{q_{i s}}{1-q_{i s}}\right)^{3 / 2}
$$

で与えられる.この $P$ の值は, 式 (19) の平均化にお いて, 系内の地下水流出水の持つ重み 1 亿対する河川流 入水の重みを意味している.

Fig. 14 は $F$ の值を媒介变数として $q_{i s} \sim P$ 関係を 示したものである. 図からわかるように， $q_{i s}=0.8, q_{i 1}$ $=0.2$ の場合, 寸なわち, 上流よりの河水流量が系内の 地下水流出の 4 倍の場合であっても, 平均化の重みの比 は, 後者の 1 亿対して, $F=0.2$ の場合で $P=1.6$ 倍, $F=0.1$ の場合では $P=0.8$ 倍となっている. また, 河 水と系内地下水流出が量的に等しい $q_{i s}=0.5, q_{i 1}=0.5$ の場合では, $F=0.2$ に対して $P=0.2, F=0.1$ に対し て $P=0.1$ 程度と $P$ の值はかなり小さいことがわかる. すなわち, 河水としてかなり多くの水量が系内に流入し ていても, 式 (13), (19) の平均化過程でもつ河水の重 みはかなり小さい, いい換えれば, 系内地下水流出分の 重みの方が相対的に大きいことになる.

ここで解析した領域では, 53 個の低減部のうち, $q_{i s}$ が 0.9 より大きいのは 6 例に過ぎず，ほとんどは， $q_{i s}$ が約 0.2 約 0.8 程度であった. また, 前節で述べたよ うに，Fの值は大きくとも 0.2 程度までであることを念 頭に置いて Fig. 14 を見れば, 最下流端での低減特性 $K$ を定めるうえで, 系内の地下水流出水の 重みがいか に大きいかが理解されよう.このように，一つの流域に あって, 河川水, より上流部よりの流出水の果たす役割 は小さく, 低減特性は主として観測点のすぐ上流位置 する力学系の性質によって定まるのである. 実際の流域 は力学系の連鎖からなっているわけで, 式 (13) で与え 
られる平均化が繰り返し起こっていると考えられ，しか も上記のように, そのつど力学系内の特性に左右されて いると考えられる.

\section{8. 流域構造とランピング}

\section{（1）流 域構 造}

ここでは, 地下水流出に対する流域を, どのような構 造モデルとして捕えるべきかを考えよう。これまでに議 論したことがらを返り見れば，考えるべき構造は，次の ことがらを合理的に表わすものでなければならない。す なわち,

i ） 流域は力学系の連鎖として表現されること，

ii ）地下水流出の特性自身は, 本質的には地下水帯 内の流れで決められること，

iii） 流域面積によって場所的スケールが定められる こと，

iv） 個々のスケールの範囲内では, 特性量は流域面 積の増加に応じて一定の法則にしたがって連続的に変化 するが，次のスケールへの遷移では不連続的変化をす る,

v）上記のスケールの分類が，流域のオーダーと結 びつけられること,

vi） いくつかのスケールへの分類にもかかわらず， 巨視的には式 (15) の仮定が容認されること，

vii） 個々のスケール内部での 特性量の変化・平均化 過程が 7. の議論で説明されること，

viii）構造はあまりに抽象的になり過ぎず，実際の流 域の地形状態などを合理的に表現すること， である。

これらの条件を満たす流域の構造として考えたのが Fig. 15 である. このような構造については, 概念的に

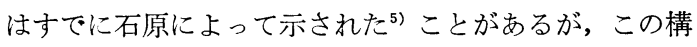
造が前章までで得られた 結果によって具体的に裹 ゔけられることがわかろ 5 .

図中のいくつかの領域 について，その場所的な 広がりを考えれば，たと えば上記 ii）や vi）の 条件も認められるである う.これらの領域の分類 は物理的には地下水の流 線によるが，流域の地表 形状との関係でもかなり

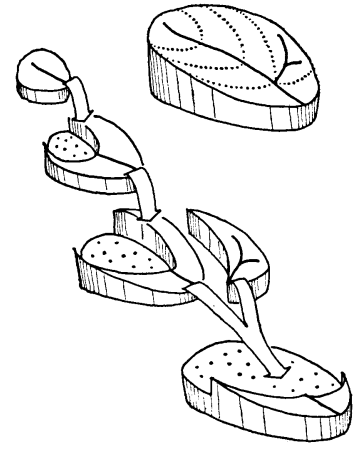

Fig. 15 Watershed structures for ground water runoff.
はっきりと分類されるのは興味深い。

\section{（2）流域のランピング}

流出のモデルは大別して, lumped system model と distributed system model に分けられる. distributed model は特性曲線法などに代表されるが，従来は洪水流 出を対象としたもので, 地下水流出を対象としたものは まだないといってよい． 3. で述べた分布系としての扱 いも, 地下水の流出を念頭に置いているが, 実はまだ流 出のモデルという形式に書き直されていない. 従来はほ とんどすべて lumped system model で解析されてきた のである.実際の流域は, 線形であれ, 非線形であれ, 一つの lumped model, あるいは, いくつかの lumped models の組み合わせとして扱われていた. しかし，こ のような扱いにもかかわらず，どのような流域では一つ の lumped model として扱いらるのか, あるいは扱い えないのかという問題については議論が久落していた.

さて，Fig. 9 をふり返って低減特性 $K$ のばらつき が小さい流域, 7. の議論によれば, 流域の状態が一様 であるか, 平均化過程が非常に卓越する流域では, 流出 の特性が時間不変の流域固有の值として特定されるわ けである. すなわち,こうした流域は 1 つの lumped model として扱いらるはずである.一方, 低減特性值に 大きなばらつきのある流域では, 場合場合の水の場所的 分布状態いかんで系の特性が左右され, 水の場所的分布 の様子を考慮せ斌ばならない.すなわち, 分布モデルに するとか，より小さい流域に対する lumped model の 組み合わせにするといった配慮が必要となる.もちろ ん, 7. (2) で比較した角, 上田地点のように, 流域自身 のもつ地形地質的特徴は考慮せねばならないが, Fig. 9,

Table 1 は前述のスケールの問題と同様, 地下水流出 についての流域ランピングの一つの評価基準を与えると いえるであろう。

\section{9. まとめ}

地下水流出の代表的な特性, 流量低減特性を取り上 げ, その流域内部での変化過程, 流出のスケール, 流域 の構造を論じた. 本研究で得られた結果を要約すると次 のとおりである.

（1）地下水流出の特性は地下水帯内の流れの特性に よって定められるが, 流出現象のスケールは流域面積に よって, Table 1 のように分類される. かつ, このス ケールは流域のオーダー, すなわち, 流域における集水 過程と密接な関連を持っている.

（2）個々のスケールの現象では，低減特性は流域面 積の増加に応じて一定の法則（流域面積に反比例）にし 
たがって変化するが，次のスケールへの遷移に際して は, 特性量は不連続的に変化する.

（3）個々の力学系では, 特性量は式（13）で示され る加重平均化過程にしたがって平均化・一様化されてい る.

（4）ある流域の特性は，主として流域最下流端に位 置する力学系の特性に左右され, 上流部領域のもつ重み は比較的小さい.

（5）流域はいくつかの力学系の直列・並列の連鎖と みなされるが，流域は Fig. 15 に示した構造として捕 えるべきである.

（6）以上の議論を基礎に，地下水の流出を扱ららえ で, lumped system として扱いうる流域, distributed system あるいはより小さな lumped system models の 組み合わせとして扱うべき流域の判定基準の一つのめや すが得られたこと.

などである。

1.で触れたように, 流出現象のスケール, 平均化過 程といった問題は, その重要さが指摘されつつも, 特に われわれの眼に直接に触れない地下水流出については論 議されず見過されてきた感が強い。本研究では，低減特 性といった唯一の性質を取り上げたに過ぎないが，それ は地下水流出の重要な特性であって, ここで得られた結 論は上記の問題解明に 1 つの新しい指針を与えうるであ ろう。
本研究は, 著者の 1 人高木が客員教授として, 西ドイ ツ・アーヘン工科大学滞在中に行った共同研究の成果の 一つである.本研究の遂行にあたり,西ドイッAlexander von Humboldt Stiftung 財団より多大の援助を受けた ことを記すとともに，筆者らに共同研究の機会を与えら れたアーヘン工科大学土木工学科の Rouvé 教授譁ん で感謝の意を表したい.

\section{参 考 文 献}

1）高木不折：低水流出の低隇特性に関与る研究，土木学会 論文集, 第 128 号, pp. 1 11, 1965.

2) Takagi, F. : A Study on the Dynamic Process of Ground Water Runoff, Memoires of the Faculty of Engineering, Nagoya University, Vol. 23, No. 2, pp. 221 284, March, 1972.

3) Takagi, F. : A Study on the Behaviour of Basin Water by means of the Variational Technique, Proc. JSCE, Vol. 185, pp. 71 81, Jan. 1971.

4) 高木不折: 流域水の挙動に関する变分原理の物理的意義, 土木学会論文報告集, 第 227 号, pp. 27 32, 1974.

5) 石原安雄: 水文サイクルと数理モデル, 水工水理学, 第 8 章, p. 311, 丸善, 1972.

6) Strahler, A.N.: Quantitative Analysis of Watershed Geomorphology, Trans. Am. Geophys. Union, Vol38, pp. 913 920, 1957.

7) Fusetsu Takagi : Variation and Changing Processes of Recession Characteristics in watersheds, Mitteilungen Nr. 19, Institut für Wasserbau und Wasserwirtschaft der Rheinisch-Westfälischen Technischen Hochschule Aachen, pp. 5 67, Okt. 1977.

(1977.7.20 • 受付) 